\title{
Marconi Death Ray: Not Only an Italy-Vatican Tale
}

\author{
Carlo Artemi \\ Pubblic Instruction Department, I. C. "Largo Oriani”, Rome, Italy
}

\section{Email address:}

carloartemi@gmail.com

\section{To cite this article:}

Carlo Artemi. Marconi Death Ray: Only an Italy-Vatican Tale. History Research. Vol. 4, No. 1, 2016, pp. 1-5. doi: 10.11648/j.history.20160401.11

Received: February 17, 2016; Accepted: March 1, 2016; Published: March 12, 2016

\begin{abstract}
Guglielmo Marconi has long been regarded as one of the greatest personalities of the history of science and technology of the twentieth century. A writer, citied in the text, has called him "The father of radio, the great grandfather of TV and the great, great grandfather of the Internet" (at least of Wi-Fi). Many things, both positive and negative, have been said about him. Perhaps the most famous story about him concerns his "death ray," a formidable weapon, operating by radio waves, able to kill a great many people and to destroy tanks, airplanes, and ships. According to serious historians, these are purely tales. This, however, is not the author's views. Starting with what is known, and given the evidence of some recent particle-beam weapons tests and some elements of the story that have gone unknown until today, the author has deduced that Marconi could have had a clear idea of how to make a particle-beam weapon without even trying to build one.
\end{abstract}

Keywords: History of Physics, Guglielmo Marconi, Radio Technology, Italian Scientist, History of Arms

\section{Introduction}

The history of science and technology is one of discoveries, inventions, and more or less prescient insights, accompanied by more or less difficult relations among scientists, inventors, and individuals who are strangers to the scientific environment. But it is a story of rumors and real fairy tales, too. One of the most famous is that of the death ray that is rumored to have been invented by Guglielmo Marconi. Serious historians have always claimed that it was only a legend created by fascist propaganda to make wartime Italy appear stronger than was the case in reality. This is not the author's opinion. I asked myself: Are the tales of Marconi's death ray only gossip, only legends? Certainly Marconi didn't realize the practical development of such a device, but could he have had the idea of how this weapon could be realized? In this article, an answer to this question will be attempted.

\section{Tesla and Others}

In the 1920 s and $30 \mathrm{~s}$, when many scholars were studying the practical applications of radio waves, some of them affirmed to have built a radio death ray [1], [2]. This was conceived as an apparatus able to concentrate very high levels of energy on a target (people, tanks, airplanes, ships, animals) to such a degree that people were killed and targets destroyed. A number of these individuals were not famous scholars and they failed to give any practical demonstrations of these devices. However, among these claimants was Nicholas Tesla, a famous and prolific inventor, a true pioneer of variable currents and three-phase electrical systems. He is now recognized as the man who perhaps managed to transmit signals, or at least energy, previous to Marconi's successful efforts. Accordingly, Tesla's statements deserve to be taken seriously; in 1937, the inventor made [3] the following statement:

None of my inventions contemplate the use of any so-called "death rays." Rays are not applicable because they cannot be produced in requisite quantities and diminish rapidly in intensity with distance. All the energy of New York City (approximately two million horsepower) transformed into rays and projected twenty miles, could not kill a human being, because, according to a well-known law of physics, it would disperse to such an extent as to be ineffectual. My apparatus projects particles, which may be relatively large or of microscopic dimensions, enabling us to convey to a small area at a great distance trillions of times more energy than is possible with rays of any kind. Many thousands of horsepower can thus be transmitted by a stream thinner than a hair so that nothing can resist it. 
The description is not very precise, but it is clear that Tesla was speaking about a real object, not some vague idea. This object would very probably have had to have been a particle-beam weapon. Other subsequent statements of Tesla confirm this. It is clear that Tesla thought it was not possible, due to diffraction, to concentrate the energy of radio waves in a narrow beam. Certainly, Tesla didn't know about or underestimated the effect of lasers. In addition to the statements of the scholars, there were, in those years, also testimonies of people who affirmed to have seen the effects of the death ray or alternatively of a paralyzing beam that was able to remotely lock the engines of cars or aircrafts. Among these people [4] was Rachele Mussolini, wife of the Italian dictator Benito Mussolini. In her biography, she talks about her car, which had been blocked by a paralyzing ray patented by Marconi. Serious historians have always considered this and other similar claims to have been purely tales created by fascist propaganda to represent Italy as being stronger than it was in reality.

\section{Some Recent Tests}

It has been documented that during WWII, Germany and Japan had several projects to realize a death ray, probably a microwave ray. However, no evidence exists that any of these weapons were tested. Tesla tried to sell his weapon, which he called "Teleforce", to the USA Department of defense, too, but with no success. In recent years, the USA, Russia, and China have claimed to have realized and successfully tested particle-beam weapons, particularly laser ray weapons. Almost certainly these weapons aren't Marconi's death ray but are very similar and overall are the demonstration that particle-beam energy arms are not a product of fantasy but they are, at least today, real weapons. In particular, the US Navy have posted on YouTube some interesting videos. In one of these[5], a laser gun, well visible in the video, installed in a military ship sailing in the Persian Gulf, shoots down a drone and strikes a small ship. While the targets are not completely destroyed, they are hit and damaged by laser rays. In another video, [6] a Quassam-like rocket is hit and destroyed by fire from a laser gun. It is worth noting that Quassam rockets fired by the Hamas movement against targets in Israel have been hit by laser guns mounted aboard Israeli naval vessels. By viewing this video, it is possible to roughly estimate the destructive capabilities of such a weapon. Starting with the typical dimensions of Quassam rockets and from direct measurements taken from the online video, it is possible to estimate that the laser ray liquefies a cylinder of 20 centimeters in height and with a base 20 centimeters in diameter. Let us suppose an average density of materials used to make the rocket equal to $\mathrm{X}$ and supposing a specific heat of these materials equivalent to $1 / 10$ of the specific heat of water and supposing 5 seconds of time need to liquefy the material, a value of 1 megawatt (as order of magnitude) for the needed power is obtained. It is worth noting that this power is equal to the power citied in Tesla's statement. China [7] has affirmed to have built a laser gun, too, while Russia [8] has affirmed to have built a microwave gun, not to disrupt drones but with the ability to turn off the electronic circuits of drones themselves. Now let remind Marconi in the last years of his life worked on microwaves. Not only but, supposing typical length of drones is one meter and typical dimensions of circuit one centimeter it's clear wave length of microwave used by Russian is probably of some centimeters. Several witnesses have affirmed that Marconi worked with microwave whose wavelenght was between 1 meter and 5 centimeters.

\section{An Important Witness}

There is an important witness of Marconi's purported work who is rarely citied but is very important: Adelmo Landini. Landini [9] was a brilliant Marconist (radio operator) in several Italian ships and obtained patents, too. In 1927 he was nominated as Marconist of Marconi's yacht, the Elettra, which served as a floating laboratory in which Marconi did many experiments in the 1920s and 30s. The radio command turning on the lights of the Town Hall of Sidney came from the Elettra, which was a thousand kilometers from Australia at the time. This was one of the most famous of Marconi's experiments. In that ship there was also a mysterious small laboratory in which only Marconi could enter. This room was called "the chemistry lab," [10] and no one knew what kind of researches were conducted within it. It was thought that Marconi studied here the so-called "lightweight battery," a battery light enough to fit inside a ship, but sufficiently powerful to give energy to electric motors to move the ship itself. But it seems that Marconi also studied the influence of radio waves on plant growth in that room. The only thing that is certain is that the physicist Anselmo Landini once, and only once, saw what was inside a container that had to be carried into this room, which was a container full of ammonia. It is worth noting that ammonia can be related to plant growth but not to batteries.

Furthermore, Landini lived for five years as a close collaborator of Marconi and often he spoke with him on topics outside the technical field, too. Landini wrote a book on these experiences and in this book there are things, in the author's opinion, that have great relevance to the possible reality of death ray claims.

In 1927 there was an interesting discussion between Landini and Marconi. [11] Marconi, after stating he wanted to study energy transmission, at any radio frequency range, added (the words of the book are quoted verbatim):

"I am sure there must be in the middle of the frequencies spectrum, a frequency able to kill more or less rapidly a particular microorganism."

"A well defined frequency?"

"As many frequencies as the number of microbes. In short, enough to resolve the diseases of man, animals, and plants."

These words are surprising. It is clear Marconi really thought about a death ray, but for the purpose of killing the microbes responsible for diseases. It is also evident that Marconi wasn't thinking of UV rays, which are bactericidal but do not penetrate inside the body, as radio wavel do.

In the same period, an interesting discussion [12] occurred 
between Marconi and Raffaele Lauro, who was the commander of the Elettra. The topic of this discussion was war, in particular who would win future wars. The exact words of the book are as follows:

"He (the commander Lauro) argued that strategy and tactics should be considered deeply modified by the new offensive weapons . . . that military science would have no more truces, due to the pressure of progress, which would create a continuous change of the warfare tools with innovations not always measurable because secret.

"So you would say it will not be the strongest numerically that will win but who at any given time will have more means to produce hellish secret weapons, 'Marconi affirmed."

"As likely; it's hard to be able to say, 'Lauro said.

" If a war were to occur again between large European nations, it would be a disaster . . 'Marconi concluded."

Today, these words seem prophetic, but the important things to note about this discussion are the following: 1) Marconi seems substantially in agreement with Lauro on the opinion that future wars would be win by whichever combatant power could produce new types of weapons, not by which would have more soldiers or more weapons. 2) Marconi conceived of future wars as a disaster. 3) When he wrote the book in 1938, Landini still remembered those words; then, he had been shocked by them. Surely these words would have shocked Marconi, too.

Besides, if one reads Landini's book, one knows Marconi had the ubiquitous idea of energy transmission. Not the transmission of voice, text, images, but energy as such. Obviously, this meant wireless transmission by radio waves. In one point of the book, the following is written (words taken from the text of a conference [13] held by Marconi in New York in 1928):

"I hope that you won't consider me to be a dreamer if I foresee the possibility of transmitting and gathering energy at a great distance by electromagnetic waves concentrated in many parallel beams of minimal dispersion."

Let us carefully think about these words. First of all, there is a strong similarity between these words and similar speeches by Tesla. Second, it is evident the energy transmission system imagined by Marconi was not for the purpose of powering a house but a city or several cities. In which case, the power transmitted by such a system had to be approximately one megawatt, or of the same order of magnitude cited both by Tesla, speaking of his teleforce, and by Russian scientists, speaking of their actual microwave gun. Third, this system had to utilize microwave radiation because only by these waves could the rays be collimated. Marconi, speaking with Landini, told him that microwaves collimated more often than short or long radio waves.

\section{Vatican Experiments}

During the 1930s, Marconi spent much time to realize the Vatican Radio. Pope Pius XII (AchilleRatti) strongly felt the necessity for the Pope and the Holy See to have a radio-transmitting capability that would permit the Pope to speak with all the world. This pope was a great fan of radio and of technology, too. On the day of the inauguration of the Vatican Radio, Pope Pius XI wanted personally to test the quality of transmission and reception of signals. Probably Pope Pius XI had some competences in the radio field, too. In 1945, Mussolini, [14] in an interview affirmed that Marconi had proposed a death ray, but he didn't want to realize it because Pope XI had convinced him not to build it. Now in 1945, Pope Pius XI and Marconi were both dead, Mussolini had lost the war, and probably these speeches were the desperate attempt to justify the defeat in front of History. But three days before dying, Marconi really [15] did meet the Pope, though the topics treated in their meeting have never been revealed. Degna Marconi, [16] Marconi's daughter, has spoken on personal questions such as the topic of this meeting, but a historian [15] has pointed out that Marconi could have spoken about personal questions to a collaborator or/and a confessor. Instead, Marconi went to the Pope. Besides, Marconi had long suffered from heart troubles and he went to the Pope only three days before his death, probably when he realized his death was very near. Not only that, but a few hours before he died, Marconi confided to his personal physician, [15] Dr. Pozzi, that "some things that only you must know" and that no one has ever known. So it is more than plausible Marconi had a secret to confide only to a very few people. What is certain is that during the 1930s, Marconi lived several times inside the Vatican State and conducted many experiments with microwaves and, during this time, he first had the idea for a radio localizer, a first type of radar. More precisely, this idea arose from a fact observed during the test of a microwave beamed between Vatican Radio and a receiver in Castel Gandolfo (a small town near Rome where the Pope had and has a palace). Regarding this, there are two versions about the event, suggesting Marconi used these experiments to prove the use of microwaves for radio-localization. In an book [17], it is written that, when checking the received signal level, it was possible to detect some oddities when a gardener carrying a metal mower passed in front of the transmitting antenna, and this suggested to Marconi and his collaborators the idea that an object could reflect microwaves.

But when the author visited the historical museum of Vatican Radio, employees of the radio who accompanied him, told him that every time a plane passed through the Vatican Radio offices and Castel Gandolfo, there was a noticeable degradation of the signal that arrived in Castel Gandolfo, and a book confirmed this version of facts. [18]. However it happened, it is historically established that these observations led to further experiments. These experiments were performed in Santa Marinella, a small town on the sea near Rome, in a radiotelegraph station owned by the Italian Navy. The author found on the Internet an article [19] by a teacher, working in this city, who had posted some very interesting photos related to Marconi's activities in this place. In the first photo, the building with a tower used by Marconi is shown. On top of the tower you can see a transmitting parabolic antenna of about one meter in diameter. The antenna is not fixed, but it can rotate in every direction. The antenna's dimensions make us 
understand that Marconi worked on microwaves whose wavelength was much less than one meter; probably their wavelengths were some centimeters, which were the same wavelength on which the microwave gun claimed by Russian scientists works. In the second photo you can see a car model "Balilla", of Italian manufacture, and on the back of it there is a receiving antenna. This antenna also has a parabolic shape, of about one meter, and in the article it states that it was used to effect mobile communications between the car itself and the transmitting antenna. Remember the episode recounted by Rachele Mussolini. In the third photo, (present in [20] too) you can see Pope Pius XI, who is holding a receiver very similar to current mobile phones. From the picture, it is not clear where it was taken, but the article says that the Pope was probably inside the Vatican City and was talking with a person, perhaps Marconi, who was in the Chiaruccia Tower station. This fact makes us understand how much the Pope was interested in the radio techniques and strengthens the idea that the Pontiff should also have a certain expertise in the field. From other sources [21] we know that experiments were conducted at Chiaruccia Tower, one of which was in the presence of Benito Mussolini, on the possibility of receiving a reflected signal from an airplane in flight. During these experiments, the microwave beam was pointed at the aircraft. It is worth noting that after Marconi's death, these test were continued, although at a slower pace, and in 1942-1943 some radar devices were built by an Italian firm and were installed on several ships; among these was the battleship Roma, the mother ship of the Italian navy.

\section{Conclusion}

So far we have set out several facts.

Marconi was perfectly aware of the fact that radiations and radio waves, too, could be harmful to living creatures, and that he also he spoke about microbes in this respect

Marconi was a pacifist or at least he was convinced that a future war among the big European countries would be a disaster.

Marconi was able to provide an apparatus able to focus a collimated and very directional radio waves beam

Marconi was aware that it was necessary to realize a high-power radio waves beam to transmit energy at a distance.

Pope Pius XI was very interested in the technological developments of the radio and he probably understood something about it, too. Certainly Marconi and the Pope were friends.

Now, by exercising a little fantasy, we can think about these facts in this way. In the 1930s there was a deterioration of the international political situation with the rise of Hitler to power in Germany. A Marconi convinced of the technological revolution being brought about by radio could realize and be aware of both the dangers radio waves could bring to living organisms and of Captain Lauro's way of thinking (which very probably was Marconi's way of thinking, too) regarding the possible destructive power that a collimated and very energetic radio wave beam could bring against men, ships, and airplanes. After the first Santa Marinella test, Marconi understood that he had realized such a collimated beam. This beam lacked only a megawatt or dozens of megawatt power to be used as a weapon This awareness frightened Marconi, made him listen to the scruples of his conscience, and prompted him to confide in the Pope and probably with Dr. Pozzi when he felt that death was very near. The Pope, as his confessor who could understand him and having an interest and some expertise in radio waves, along with Dr. Pozzi, as one who was trying to shield him from death, would have been familiar with Marconi's accomplishments and fears about this technology Last but not least, are two facts that might have had some importance in this matter. In 1932, Landini [22] accidentally briefly touched some high-voltage parts of the transmitter of the Elettra. He was not electrocuted but had some physical problems so severe that he had to abandon collaborating with Marconi in experiments. So Marconi saw with his own eyes what could happen to a person if hit by a strong dose of energy. As already said, the only time Landini could know what was being brought into the mysterious chemistry lab, he saw ammonia. But in 1953 the maser, which is the equivalent of the laser using microwaves, was made just by using ammonia as the active material. Just a coincidence? It may be, but a maser-powered amplifier could be the missing link between the Santa Marinella transmitter and a microwave gun.

\section{References}

[1] www.wikipedia issue "death ray".

[2] William J. Fanning Jr.” Death ray and the popular media: 1876 1939”, Mac Farland and Co, 2015, pagg. 49-76.

[3] http://www.pbs.org/tesla/res/res_art11.html.

[4] R. Mussolini, "Mussolini privato", Milano, Rusconi Editore, 1973. pag 111.

[5] https://www.youtube.com/watch?v=jIxugT-QiEI.

[6] https://www.youtube.com/watch?v=kgUnDeED9MM.

[7] http://www.popsci.com/chinese-soldiers-have-laser-guns.

[8] http://www.popularmechanics.com/military/weapons/a16044/r ussian-anti-drone-microwave-gun/.

[9] Landini, "Cinque anni a bordo dell'Elettra con marconi”, Torino, Società Editrice internazionale, 1939.

[10] Ibid, p.10.

[11] Ibid, p.59.

[12] Ibid, p.60.

[13] Ibid, p. 73.

[14] Fossani, "Mussolini si confessa alle stelle", Roma, Latinità, 1952.

[15] R. Chiaberge, "Wireless", Milano, Garzanti, 2013, pp. 288-289. 
[16] D. M. Paresce, "Marconi mio padre", Roma, Di renzo editore, 2008.

[17] G. Nascia, "la guerra senza radar", Amazon Media EU, 2014.

[18] V. Cantoni, "Storia delle telecomunicazioni “, Vol1, Firenze University press, 2011, pag 161.
[19] www.iw2en.com/app/download/.../Archivio\%2520Marconi.pd f?t...

[20] W. P. Jolly," Marconi”, Stan and Day, 1972, pag 266.

[21] W. P. Jolly,” Marconi”, Stan and Day, 1972, pag 267.

[22] Ibid, pp.150-152. 